\title{
Fruits of our labour: Work and organization in the global food system
}

\author{
Steffen Böhm, Marja Spierenburg, Tim Lang
}

Introduction to the Special Issue, to be published in Organization

\begin{abstract}
This is the first special issue of any organization studies journal on food labour. Why is this a big deal? In this Introduction we argue that the field should pay much more attention to the agri-food system and the work that goes into producing, distributing and consuming foodstuff. Food is such an all-important, basic ingredient to human existence, incorporating a vast web of organizational processes that are constantly changing, being contested at all scales. Whether subsistence peasants, new-age community foodies, massive food logistics companies, Deliveroo dark kitchens or Uber Eats cyclists - there is a huge amount of labour everywhere in the agri-food system. Food labour is so vast, this special issue can only begin lifting the lid. In this Introduction we provide an overview of the current scholarly work on food labour. We identify some of the historical contexts and struggles that have led to the agri-food system in existence today. We identify food labour types, particularly focusing on those that are vanishing or emerging, crucially asking why these transitions are taking place. We also engage with the various resistances expressed by people against the ever globalising agri-food system, outlining logics for the emergence of alternative food movements. Finally, we introduce each of the seven papers collated in this Special Issue, all of which, we hope, will provide food for thought to all of us who tend to have three meals a day without thinking too much about the labour that goes into our grub.
\end{abstract}

\section{Introduction}

In children's story books, there is often a romantic picture of food labour centred on the farmer, presented as a robust, worthy citizen, today with a tractor, in the past with horses. This 'old' picture offers a vision of short supply chains from farm to kitchen which is hopelessly inaccurate, let alone depicting the complex dynamics of $21^{\text {st }}$ century food labour (Kearney 2018). In the $19^{\text {th }}$ century, sizable labour sectors working on food, but off the land, emerged first in the West, then spread globally. Today, entirely new sectors emerged, as the gap between primary production and final consumption has lengthened. Gone is the romantic picture of doughty yeoman farmer, and in comes the reality of ready-made food, supermarkets, home delivery, advertising and marketing, data mining, plant and animal breeding, and supply chain management. Consumers have been enrolled into this restructuring of food labour, with transformation of domestic labour, the arrival of the prosumer, and Instagram identity food politics. Behind these 'new' food labours lies the juggernaut of food manufacturing, whose processes have transformed how increasingly urbanised populations receive their food since the $19^{\text {th }}$ century. Steam roller mills altered milling. Canning, invented in the early 1800s, was industrialised by the century's end. New processes and products have continued ever since. Today, hundreds of thousands of new food products come to market, many to fail, but all seeking to grow what consumers never even knew they wanted. The food designer, chemist and engineer have changed the entire food system from production to consumption. New sectors and sources of labour intervened and restructured the flow of biological matter we humans call 'food'.

Work undertaken to produce food is one of the most fundamental and ancient forms of labour human beings must engage in to survive and flourish. It is not surprising, therefore, that much of the academic focus on food work has been on primary forms, i.e. 'on' rather than 'off' the land. Thus, there are many studies of peasant labour (e.g. Bose \& Sugata, 1993; Bryceson et al., 2000; Pegler, 2015), of the transitions caused by industrialization and mechanization of farming (e.g. Laite, 1981; Heywood, 1981; Cernea, 1978), and of the role of migrant labour on the land (e.g. Cliffe, 1978; Bryceson, 2019; Chan, 2010). Yet, remarkably little attention has been given to the broader range of food labour or to see if there are any cross-sectoral similarities. Instead, mainstream understanding has taken recourse to a narrative of progress as well as that the revolution in length, complexity, control and technology of food work in the 20th century has all been for the greater good of humanity, efficiency and well-being. Now, in the era of climate change, and powerful evidence on how food is a main driver of ecosystems and health damage (Willett et al., 2019; Gladek et al., 2016), it is time to begin a more critical analysis of modern food labour. As societies have industrialized and urbanized, food remains perplexingly hidden to most of us (Li 2011). Some have argued that this is because of food's banality and 
intimacy; it is just there (e.g. Winson, 1993). Others point out that it is crises, notably hunger, which demand critical analysis, and that the $21^{\text {st }}$ century challenges are so complex, the demands tax common understanding (e.g. Mason and Lang, 2017). The need for consumers to understand more precisely how food arrives on the supermarket shelf does bubble up from time to time. It was forcefully brought home, for instance, by the horsemeat scandal that gripped Europe in 2012 (Madichie \& Yamoah, 2017), and BSE ('mad cow disease') in the 1980s-90s. Scandals such as these, as well as an increasing stream of media publications on the relations between food production and climate change (BBC, 2019) have spawned a range of consumer and policy reactions, from scepticism to changed behaviour, to moments of renewed interest in the production and regulation of food production.

This partial picture suggests room for improved understanding of the role of food work in modern systems. While there has been welcome attention to food retail (Burch \& Lawrence, 2007), there has been less focus on modern food factories, or the growth of artisanal production. Catering remains the Cinderella service in academic studies, which Gabriel (1988) noted three decades ago. Demand for local and fair-trade food, for instance, indicates some appetite for food with provenance that is 'ethically produced' (Nicholls \& Opal, 2005), though some studies indicate that even this niche has had limited impact. One study of fair-traded products, for instance, found that while benefits did flow into the developing world, women and the lowest paid workers did not receive their due rewards (Cramer et al., 2014).

The motivation for this special issue was to refocus academic attention on how change and growth in the food system and all its sectors affect those working in the agri-food system. This collection of papers can barely scratch the surface of what is really needed, but we call for others to join in beginning to lift the commodity veil and to explore the production and organization processes behind food and the context that shapes them. Some social scientists, particularly geographers, have begun to map the vast web of work which enables 'just-in-time' supply chains to deliver food to affluent parts of the world so continuously and relatively cheaply. They also highlight the costs, winners and losers (Allen \& Sachs, 2012; Bonanno \& Cavalcanti, 2012; Cramer et al., 2014). As a transition unfolds from an era of low food prices to one characterized by, what Moore (2015) calls, 'the end of cheap nature', the full costs and scale of production assume even greater importance (FOLU, 2019). Yet, the costs and benefits within the agri-food system are unequally distributed among the various actors in the system (Elder and Dauvergne 2015); Van der Ploeg, 2009). Increased financialization (Clapp), a growing dominance of the food system by large agri-businesses (Lang \& Heasman, 2015), as well as policy contradictions, characterized by the promotion of intensive production methods, on the one hand, and sustainable rural development on the other, have impacts on this distribution (Banks \& Marsden, 2000; Garzon, 2006; Siebert, 2006). At the same time, there is greater awareness among both policymakers and the wider public of the unacceptable social costs of cheap food, in terms of environmental costs as well as exploitative and unsafe conditions for workers and food producers across the system (Burnett \& Murphy 2014; De Castro et al., this issue).

Even apparently simple foods may have complex supply chains. One study of factory-made bread found at least 40 ingredients, meaning suppliers did not necessarily know what was in their products. The myriad segments which now make up what analysts call the 'food system' are subject to co-ordination, negotiation and rapidly changing dynamics. Within these market relations, there can be moments of unprecedented stress. One moment, the food labour force is extending, the next it is fragmenting. One moment, in the worlds of Marx and Engels in 1848, rural labour was being liberated from what they memorably called the "idiocy of rural life" and seduced into an apparently freer life and labour in the town, the next their labour was being exploited or marginalised. This vacillation is still observable today, across both rural and urban food work. Think of the casualization of the Uber or Deliveroo food delivery bicyclist (Taylor, 2017). Across diverse political regimes, the price of food is a significant indicator of progress and development (Bernstein 2014); (Dorward 2013). Food prices have also served as political instruments, with attempts to control prices to keep wages of labour in other economic sectors in check and suppress social unrest. As sectoral interests vie for control, market share and profits, the labour process is ceaselessly under review. Investments and technological innovations serve to 'modernize' food production and increase production, yet the concomitant financialization of food production also results in price increases, which have scarcely improved livelihoods of food producers. Value chains have become longer, resulting in a 'distancing' in food systems (Clapp). New sectors and actors have emerged, seemingly overnight, snatching the food just before the consumer gets to 'choose' it, thereby taking another slice out of the chain. Internationalisation of value chains increased under new wave globalisation from the 1970s, and further accelerated with a new land rush since the early 2000s, involving players from emerging economies as well, further reinforcing the squeeze on food work (Lang and Heasman 2015, Devlin 2016, Devlin et al. 2014, Cousins et al. 2018). 
Why does this background matter for understanding the role of labour within organizations? Simply because food ought to be an immense slice of labour and organizational analysis, but it rarely is. There is hence an urgent need for organization studies to take the human labour element in food more seriously, from farm or sea to consumption and waste. Food systems offer rich opportunities critically to examine the role of work and labour in all societies, whether high, middle or low income, whether looking at primary production or the new 'soft' people control sectors such as Big Data workers or Uber drivers. Food labour is so vast, so all-present, that this special issue can do no more than begin to lift the lid. People and hence organizations cannot go without food for long, and it is somewhat curious that food has been ignored in organization studies for so long. The purpose of this special issue is to begin to change that and to put the case for food as a core exemplar within organizational analysis.

\section{Food labour in transition}

The food sector has always been the largest labour force on the planet. In the past, work was as serfs or slaves, whereas today it is more often waged. There is still a vast unwaged labour force, however, with possibly nearly half a billion people working in the micro-scaled subsistent (self-providing) farm sector. Industrialisation accelerated a revolution in agricultural work, partly by technical innovation replacing labour, and partly people being attracted into towns and cities. The world is now majority urbanised, yet the International Labour Organization (ILO) estimates the global farm labour force still to be over 1 billion people, one in three people in employment. This is now in decline both in absolute numbers and proportionately. Back in 1991, farm labour was an estimated 1.3 billion, $42 \%$ of all employment but by 2017 this had fallen to $28 \%$ (World Bank 2018). These global figures disguise massive regional differences. In 2017, the ILO estimates that agriculture employed $70 \%$ of the workforce of low-income countries, nearly $40 \%$ of lower middleincome countries, $16 \%$ of upper middle income countries and just $3 \%$ in developed countries.

With economic development work moves off the land, yet labour demands in or related to the food sector remain high. This began in the industrialised West in the late $18^{\text {th }}$ century but runs apace today in the Asian Far East and other parts of the 'developing world'. Much land-based food labour was and remains unwaged, working hand-to-mouth in small scale self-sufficiency (International Labour Organisation 2018b). About two thirds to three quarters of all food produced on the planet is actually produced by peasants and small units. However, with the new wave of investments in land, these producers are increasingly threatened and made to give up their land in return for a promise of jobs in more 'modern' agriculture (Li 2011). Plantation agriculture is not a thing of the past; it is alive and well but now facing environmental as well as occupational scrutiny.

Although formal employment has grown, much of it is insecure, temporary, part-time, or semi-waged (Scherrer and Verma 2018); (Li 2011). The labour force is both casualised and feminised and gender pay gaps are considerable (International Labour Organisation 2016). Despite legal abolition, slave work continues, with forced agricultural labour a significant segment of the estimated 21 million forced labourers in the world (International Labour Organisation 2014).

The experience of these workers ranges from slave-labour aboard Thai fishing boats (Vandergeest 2018) to volunteer work by the home or allotment gardener, producing food for their own table (Watson, this issue), from exploitative rhythms of migrant agri-food labourers in rich countries (Manolchev \& Agar, this issue) to modes of exploitation in the agricultural fields in poorer nations (Greco, this issue). The policy response to this running sore has been honourable but weak, a mix of niche markets such as fair trade and appeals to responsible capitalism such as the FAO and OECD's voluntary Guidelines on Responsible Reporting (OECD and FAO 2015 ). No wonder there has been a renewed interest in new peasant organizations and the wider resistance to corporate farming (McMichael 2000, Martinez-Torres and Rosset 2010).

\section{Growth of food labour off the land}

Food work is everywhere but much of it is hidden. The tea picker, the canteen worker, the supermarket checkout worker, the horticultural worker, the factory sorter and packer, they all keep just-in-time food systems flowing. Food labour is nigh universally low paid, yet modern media have lionised celebrity chefs. Few, other than for niche markets such as fair traded foods, argue that food ought to cost more to ensure food work is properly rewarded. Questions about how to feed the growing world population result in a fierce battle over what is meant by efficiency between those who see it as financial productivity per worker and others who offer new criteria such as carbon emissions or people fed per hectare (Cassidy et al. 2013). 
As the food manufacturing revolution emerged in the $19^{\text {th }}$ century, with machine production seemingly offering the prospect of minimal food labour, some radicals began to argue that the drudge, the mundanity and exploitation might even be something of the past. Charlotte Gilman Perkins, for example, a radical feminist, foresaw a time when domestic life could be kitchen-less, thus liberating women (Perkins Gilman, 1966). Less thought was then given to where that labour might be transferred or on what terms. Yet, a modern feminist focus on food has suggested that the reproductive politics of food has not gone away (Lewis and Schuller 2016). In the early $21^{\text {st }}$ century, food, as we have seen, remains a huge employer. Perhaps this should not be a source of surprise. As a basic need, some labour, whether waged or unwaged, conducted by men or women, young or old, is likely to be expended on feeding people. What is remarkable, however, is the rapidity of change in food labour. Settled agriculture began around 10-12,000 years ago. Industrialisation took off 200 to 300 years ago, and went global only in the last century. And a transformation of food processes has occurred in the last century and a half. 'Supermarketisation' began in 1916 with Clarence Saunders' surreally named Piggly-Wiggly self-service store (Lawrence and Dixon 2015). Yet, that is now being constantly changed by new products, new processes which result in new pressures on and new ways of organizing labour; for instance home delivery of prepared food by drones, new software platforms, such as Amazon Fresh, and under-paid freelance food couriers on bicycle, clashing with motorists in traffic clogged big city streets. An 'Uber-isation' of food processing and delivery is underway.

Battles for control of food markets are a permanent feature of the food system. In the late $19^{\text {th }}$ century what are today new food manufacturing giants began: Nestlé in 1867; Quaker Oats in 1877; what is now Unilever in the 1890s; Kellogg's in 1904; Coca Cola in 1892 and Pepsi Cola in 1898; General Mills in 1928. Today the giants emerge fast. A company such as Just-Eat is a web-based delivery company which orchestrates home deliveries from multiple restaurants. It was founded only in 2001. It was floated on the London Stock Exchange in 2014, valued as $f 1.4$ billion and by the end of 2017 was valued at $f 5.6 \mathrm{bn}$. Its worth was greater than Domino's Pizza founded in 1960. Amazon, the huge online retailer, was founded in the USA in 1994, launched Amazon Fresh in Seattle in 2007, rolled it out in 10 countries within a decade, and could undercut even giant supermarket chains such as WalMart and Tesco by an average of $12.5 \%$ by 2018 (Halliwell 2018). Some financial analysts think this pace and scale of change will continue. Others argue that planetary boundaries and inefficiencies of material use are beginning to catch up on the profligacy of $21^{\text {st }}$ century consumerism (Lang and Heasman, 2015; Walker, 2019). Moore (2015) suggests that neoliberal capitalism has run its cause as it reaches its limits of providing cheap food to a growing population. Hence, he argues that an economic, political and cultural readjustment is inevitable.

\section{The variety of food labour}

There are many forms of food labour. Some uses ancient technology such as hand tools for hoeing, picking crops, sorting, cleaning, bagging, weeding. These are ancient tasks one can see on fields around the globe or painted in ancient manuscripts. No wonder peasant labour has been so extensively covered (van der Ploeg 2008). Its simplicity and low capital costs reinforces its resilience and resistance to degradation and appropriation (Herrera and Kin 2015, Scott 1976). The social fall-out from technological innovation in field labour has been much studied by historians (Hobsbawm and Rudé 1969), noting the winners and losers and sources of resistance. Contemporary technical change continues to be both championed and resisted in the food sector (Lowe, Phillipson, and Lee 2008, Grunert and Traill 1997, Bigliardia and Galatib 2013, ACARD 1982). As a result, some parts of the world see food emerging from equipment and labour process which would not have been out of place a thousand years ago, while elsewhere in the world vast new equipment is applied in manners even half a century ago would have seemed impossible: genetic engineering, drone managed crops, roboticised food factories, retort pouches not just tins or frozen foods. Labour displacement may continue apace in one part of the world while not in another.

For at least ten to twelve thousand years, since settle agriculture emerged, food has always travelled and been traded, but today the scale of that movement is immense. Ships, trucks, trains and planes carry food far and wide. This distribution labour force underpins the food system, yet few outside retail logistics consider them part of the food labour force. With computer-based just-in-time distribution systems now the epitome of conventionally 'efficient' food supply chain management, a new hidden food labour force has become increasingly powerful. Long-distance truck drivers are the new coolies, but they might be displaced from home, constantly on the move, yet can be well paid, although not all are. Supermarket logistics go hand in hand with ruthless buying systems. Fresh food products are contracted a year ahead but are stored for perhaps only 4 days; the storage is on the motorway. The food planner and 
retail category buyer is sovereign in their tiny segment. Buying consortia of supermarkets in which they, too, are but cogs, now exert massive negotiating power. This is not a market but hypermarket economy.

One of the most transformed food labour sectors is in food service. In some countries, this is now vast. In the UK, for example, out of a total food labour force of 4.1 million in 2018, there were 1.83 million catering workers, dwarfing retailing's $1.17 \mathrm{~m}$, let alone manufacturing's $0.45 \mathrm{~m}$, farming's $0.45 \mathrm{~m}$, wholesalers' $0.24 \mathrm{~m}$ or fishing's tiny $0.02 \mathrm{~m}$ (Defra 2019). Globally, the manufacturing labour force is tiny compared to farming. The ILO still cites a mere 22 million as employed in food manufacturing, the same figure it first gave in 2002 (International Labour Organisation 2018a). The World Bank, however, points to fluidity in where the future for food labour lies. It estimates that while, in low-income Eastern or Southern African countries, farming accounts for $91 \%$, manufacturing for $3 \%$ and foodservice for $6 \%$ of food labour, in a middle-income country such as Brazil farming is $49 \%$, manufacturing $25 \%$ and food service is $26 \%$. In a highincome country such as the USA, however, farming drops to $21 \%$, manufacturing is $14 \%$ and food service provides a massive 65\% of all food jobs (World Bank, 2017). As per capita income rises, the Bank expects more food system jobs to be in manufacturing and food service, and that many of these will be located in rural areas if not directly on the land.

The explosion of the food service industry demands scholarly attention. Gabriel's magisterial review of the varieties of catering labour experience is now three decades old (Gabriel 1988). It should be replicated, now including the rapid expansion of street food, food delivery work, and the growth of pre-made foods for catering assembly. A few giant corporations have emerged, which offer a mix of outsourcing and facilities management in food service. These are the French multinational Sodexo with a $€ 20$ billion turnover in 2018, and UK-derived Compass turning over $€ 23$ billion in 2018. Both employ 0.5 million worldwide and operate in at least 40 countries.

The food labour force has always included domestic labour: the cooks, the home processors, the waste recyclers. In peasant societies, food production is often part of the food labour package: the gardening, the tending and milking of animals. Social class divisions in approaches to food service have always been immense. The rich rarely cook for themselves. Low income cooking labour is and has been unwaged and overwhelmingly female. Precise labour force figures are argued over by historians, not least in relation to the labour categories (Higgs and Wilkinson 2016). In the 1851 British Census, domestic service emerged as the single largest employer of women (40\% nationally, 50\% in London), and in 1891 an estimated 1 million women, aged 15-20 years old, nearly one in three in the population, worked in domestic service (Clarke 2016, Hudson 2011).

In a sense, the rise of the modern food service sector in affluent societies is a return to domestic food labour; 'new' food labour replaced what might have been seen as 'old' or declining. This time, however, the employers are increasingly large chains and the labour process occurs out of the home. Whereas 'old' domestic labour was in-house and highly disciplined, today's food labour is often casualised, the so-called 'gig economy' (Taylor 2017).

\section{Food systems, resistance and alternative food movements}

A consistent feature of food labour markets over centuries is that periodically there are resistance movements. Peasants revolt (Binswanger et al., 1995). Factory workers down tools (de la Mare, 2008). Farm workers destroyed or undermined new technologies they perceived to be against their interest (Hobsbawm \& Rudé, 1969). And food workers have set out to create alternative systems of labour, notably through co-operatives or organisations designed to give workers more voice or actual democratic control (Ajates Gonzalez, 2018; this issue; Thompson, 1994). Throughout, the role of women both as waged and unwaged food labour has been to speak up or actively resist exploitative agri-food labour relations (Slocum \& Saldanha, 2016), and those to be both part of and lead such reactions. The gender dynamics of food work can be seen, for example, in the role of tea pickers organizing strikes (Raman, this issue) or in the urban phenomenon of guerrilla gardening (White, 2011).

Food has, at times, been used as a means to control people and sometimes entire populations, so it is not surprising that people have searched for ways to resist or escape that control. Yet, today, the many forms of resistance are globalizing, as the food system itself has been globalizing. When brands dominate markets, workers in different countries inevitably also begin to co-ordinate, and have begun to develop acute concerns about insecurity due to financialisation and economic concentration (International Union of Foodworkers, 2007; Rossman, 2013). Eliminating precarious forms of work. Geneva: International Labour Organisation. Via Campesina is one of the biggest social movements, mobilizing and organizing peasant farmers around the world, resisting land grabbing, indigenous 
knowledge theft, exploitation of farm labourers and other issues faced by land-based peasant communities (Rosset, 2013). As the lives of these peasants are often invisible to the urban populations of the globe, these struggles often remain hidden and receive relatively little media coverage or acknowledgment, even amongst progressive NGOs, politicians and activists.

Yet, food is increasingly seen as a set of practices that are embedded in a historical, globally distributed system. Such a 'systems' perspective has been one of the main theoretical lenses developed over the past decades (Ericksen, 2008; Rosin et al., 2013), with strong support now from environmental analyses, too. The world's largest conservation organisation now knows that its defense of nature requires it to press for food system change (Gladek et al., 2016). While for some authors a systems perspective mainly involves showing the integrated relations between food, people and nature (Pretty, 2002), others have highlighted the unequal distributions of power, land and access to food and markets, leading to conceptualizing the global food system as a set of 'value chains' (Allen \& Sachs, 2012), as capitalist 'regime' (Friedmann, 2005; McMichael, 2009) and historical world-system (Moore, 2015).

Equally important is the recognition of alternative approaches to organizing food systems (Michel, this issue). Local and organic food demands a price premium by customers. Agroecology, permaculture and other, more sustainable agricultural models have gained momentum across the world (Ferguson \& Lovell, 2014; Altieri, 2018; Lanka et al., 2017). Food production and consumption cooperatives experiment with different organizational models (Gonzales; Watson, this issue). While there are now very few farm labourers in industrialised countries, people increasingly long for 'going back to the land'. They enrol in community-supported agriculture (CSA) schemes (Thompson \& Coskuner-Balli, 2007), work on allotments or engage in 'adopt a pig' schemes (Watson, this issue). The movement of ecovillages is also growing around the world, where communities often strive for food sustainability and self-sufficiency (Böhm et al., 2014; Brombin, 2015). The slow-food movement is celebrating provenance and localism in food consumption (Van Bommel \& Spicer, 2011). There are also a variety of urban farming initiatives that have shown to increase people's well-being (Bharucha et al., 2019). These are all examples of noteworthy innovations and struggles in the global food system. Yet, their implications for work and labour remain under-explored. Are these alternatives really improving labour processes and livelihoods of workers?

\section{The changing faces of food labour: A taxonomy}

There are glaring gaps in academic understanding of the modern food labour process. This, we argue, is not unrelated to the remarkable dynamism of the food system itself. As we have argued, an accelerating revolution in the food system from the $19^{\text {th }}$ century to the present has altered how, whence, what and where the food labour process is driven. When migration from Eastern Europe flooded into the United States of America in the late $19^{\text {th }}$ and early $20^{\text {th }}$ centuries, often it was rural labour escaping to US cities. Classic studies were of peasants becoming urban workers (Thomas and Znaniecki 1918), or the degradation of immigrants' work in industrialised food combines (Sinclair 1906, 1985 [1906]). Migrants often build new lives by 'sharing' and exploiting their only intellectual capital, their cuisine. The varieties of cuisine on offer can be part of the allure of the city (Freudenberg and Silver 2013).

We see rich research possibilities for studying new food labour in the current phase of the food system change. Some of this is technically induced: the application of science and engineering altering or eradicating existing forms of labour. Champions of farm robotics anticipate tractor driving to be a thing of the past at field scale in the next 15 years. Some of the change is simply the effects of the remorseless concentration of food capital - mergers and acquisitions. Part of this revolution is the exploitation of software and platforms which enable tiny labour forces to control current labour by displacing existing managers, or to create new tasks entirely. One fast expanding UK consumer catering platform, Deliveroo, for example, now offers consumer meals at home from branded restaurants which no longer cook in the restaurant but in 'dark kitchens'. The kitchen dances to the tune of the online ordering consumer. The image remains that of the restaurant or named chef. Yet, these super-modern food labour processes exist side-by-side more established practices that have not gone away. Let's remind ourselves: the majority of food on this planet is still grown by peasants, often living very remotely in difficult to access rural geographies.

Table 1 summarises some, and by no means all, of what might be researched and why these are of interest. The table gives some examples referred to already in the present paper, and some new. We set out where the change occurs, with what effects, why it matters and some potential stepping stones for future research agenda. We point to the coexistence of both new and more established forms of food labour change. While Table 1 is not meant to be an 
exhaustive categorization, it indicates the wide variety of food labour that we think is worth consideration in organization studies and related scholarly fields. While there is certainly a need to understand the new forms of labour emerging in the $21^{\text {st }}$ century, there is equally a need not to forget the established food labour forms and the potentially uneven and unequal forms they take in the current period of food systems change across the world.

By sheer numbers, the existence of peasant labour is the most numerous labour force on the planet, and certainly within the food system. Academics have studied the peasantry exhaustively, with some pointing to its rise and fall (Bundy 1972), while others point to its continued survival and its vital importance in feeding about a quarter to a third of the world's population (Ricciardi et al. 2018)

Arntz et al., 2016). At the same time, as this age-old subsistence or low-technology approach to food production, a revolution in methods is also emerging, with a new phase in automation, robotics, artificial intelligence either replacing, displacing or enhancing food labour. Some of this means new skills and labour processes, too, as a much-cited OECD study suggests (Arntz et al., 2016). Software companies are now also new actors within the food economy, with mobile phone apps bridging consumers and food choice. Table 1 refers to this as 'Uber-isation' to reflect the key role that transporting food, once ordered, to the customer is now the point of control. On-line platforms take the long-term transfer of food power still further from the land. Restaurants, once a sector marked by small enterprises, now engage with the customer via deals conducted to others online, with 'dark' kitchens now emerging, removing the restaurant altogether and putting it onto an industrial estate (Veen et al., 2019; Bradshaw, 2019). If previous interventions and innovations added value by processing or retailing, this now transfers power to the cloud and internet. Different versions of 'Uber-isation' have emerged in the 2000s across the world. Now key global giants are emerging, with massive international mergers and acquisitions. And this heralds a food labour change the importance of which is much voiced but the dynamics of which are, as yet, poorly understood in publicly accessible academic output. This is the world of Big Data and Blockchain, technologies which give unprecedented power to its owners or users by retention of private control over information (European Commission, 2015; Magnin, 2016; Hellard, 2019).

Table 1 is also a reminder that some changes in food labour are by no means new. Modernised versions of 'old' transitions are manifest across the food system. Self-organised food work, such as food co-ops and alternative food networks, much studied by social geographers, shorting rural to urban supply chains, are new versions of experimentation and reaction to conventional owner-worker relations pioneered by the co-operative movement in the early to mid-19 ${ }^{\text {th }}$ Century (Thompson, 1994; Redfern, 1920; Goodman et al., 2012). At the same time, work described conventionally as low skilled and which is certainly low-waged continues across most food sectors. This is the world of delivery drivers (or bicyclists), cleaners, dish-washers, warehouse work and food waste disposal. The food system remains and is likely to remain characterised by these huge social rifts between high and low paid, the visible and invisible, prized skills and the taken-for-granted.

\section{Table 1: Some examples of how food labour is changing}

\begin{tabular}{|l|l|l|l|l|}
\hline $\begin{array}{l}\text { Example } \\
\text { of Labour } \\
\text { Process } \\
\text { Change }\end{array}$ & Location & Drivers of the change & Why it matters & $\begin{array}{l}\text { Possible futures to be } \\
\text { researched }\end{array}$ \\
\hline $\begin{array}{l}\text { Decline of } \\
\text { peasant } \\
\text { labour }\end{array}$ & $\begin{array}{l}\text { Agriculture in Latin } \\
\text { America, Asia and } \\
\text { Africa. }\end{array}$ & $\begin{array}{l}\text { This is under pressure from } \\
\text { many sides. Some argue it is } \\
\text { 'inefficient' and too small to } \\
\text { benefit from economies of } \\
\text { scale and unable to generate } \\
\text { capital to invest in labour- } \\
\text { enhancement or replacing } \\
\text { technology. Others say that by } \\
\text { operating outside the cash } \\
\text { economy, it holds back better } \\
\text { land management. }\end{array}$ & $\begin{array}{l}\text { Farms under 2ha globally } \\
\text { produce 28-31\% of total crop } \\
\text { production and 30-34\% of food } \\
\text { supply on 24\% of gross } \\
\text { agricultural area (Ricciardi et al. } \\
\text { 2018). Continuing exodus to } \\
\text { cities provides a flow of labour } \\
\text { to urban settlements. }\end{array}$ & $\begin{array}{l}\text { Will Peasant labour and } \\
\text { subsistence growers continue } \\
\text { stubbornly to survive outside } \\
\text { the cash nexus? Small scale } \\
\text { farmers often receive low } \\
\text { political support nationally, } \\
\text { although global concern (e.g. at } \\
\text { UN level) is growing, as peasant } \\
\text { movements such as Via } \\
\text { Campesina become politically } \\
\text { more organised (Duncan 2015). }\end{array}$ \\
\hline $\begin{array}{l}\text { Migrant } \\
\text { food labour }\end{array}$ & $\begin{array}{l}\text { Intra-national human } \\
\text { movement is at } \\
\text { historically } \\
\text { unprecedented scale } \\
\text { due to war, climate, } \\
\text { economics and human } \\
\text { volition. It is from rural }\end{array}$ & $\begin{array}{l}\text { This is a source of political } \\
\text { argument across the political } \\
\text { spectrum. Migrant labour seeks } \\
\text { a better life while employers in } \\
\text { the higher income zone or } \\
\text { more developed economies } \\
\text { welcome the flow of 'cheaper' }\end{array}$ & $\begin{array}{l}\text { Migration is as old as the } \\
\text { emergence of homo sapiens, } \\
\text { but today it occurs at a massive } \\
\text { pace and scale. Migrant labour } \\
\text { does the work that others may } \\
\text { reject, and the agri-food } \\
\text { system, in particular, often }\end{array}$ & $\begin{array}{l}\text { Will currently high flows of } \\
\text { migrant labour continue to find } \\
\text { work opportunities in the food } \\
\text { sector? How will the agri-food } \\
\text { sector be affected as } \\
\text { international labour mobility is }\end{array}$ \\
\hline
\end{tabular}




\begin{tabular}{|c|c|c|c|c|}
\hline & $\begin{array}{l}\text { to urban settlements, } \\
\text { e.g. } 63 \text { million in } 2017 \\
\text { within Asia and } 19 \\
\text { million within Africa. } \\
\text { Also inter-national, e.g. } \\
63 \mathrm{~m} \text { from South to } \\
\text { North America, and 9m } \\
\text { Africa to Europe, and } \\
9 \mathrm{~m} \text { Europe to Asia (FAO } \\
\text { et al. 2018). }\end{array}$ & $\begin{array}{l}\text { labour or its restraint on } \\
\text { domestic labour force wage } \\
\text { demands. }\end{array}$ & $\begin{array}{l}\text { depends on such cheap, } \\
\text { migrant labour. They are open } \\
\text { to exploitation, whether } \\
\text { working in plastic greenhouses, } \\
\text { or as semi-skilled labour in food } \\
\text { factories. }\end{array}$ & $\begin{array}{l}\text { increasingly restricted (e.g. } \\
\text { Brexit)? }\end{array}$ \\
\hline $\begin{array}{l}\text { Up- and de- } \\
\text { skilling } \\
\text { caused by } \\
\text { automation } \\
\text { and robotics }\end{array}$ & $\begin{array}{l}\text { Throughout the food } \\
\text { system, e.g. in food } \\
\text { factory conveyor lines, } \\
\text { warehouses and 'dark' } \\
\text { stores, and on the farm } \\
\text { replacing hoeing and } \\
\text { agrichemical } \\
\text { application. }\end{array}$ & $\begin{array}{l}\text { Food is witnessing an } \\
\text { acceleration of roboticisation } \\
\text { and automation (Arntz, } \\
\text { Gregory, and Zierahn 2016). As } \\
\text { some jobs disappear, new skills } \\
\text { emerge as powerbrokers. The } \\
\text { software engineers, the } \\
\text { designers of blockchains for } \\
\text { particular food supply chains, } \\
\text { and the architects of Big Data } \\
\text { mining for marketing. }\end{array}$ & $\begin{array}{l}\text { Automated warehouses or } \\
\text { factories require huge capital } \\
\text { investment. It accelerates } \\
\text { product standardisation, } \\
\text { whether in the field or factory. } \\
\text { Proponents herald it as a new } \\
\text { round of productivity advance } \\
\text { (Manyika et al. 2017). Others } \\
\text { see it as a form of deskilling } \\
\text { and loss of millions of agri-food } \\
\text { jobs. }\end{array}$ & $\begin{array}{l}\text { Are highly skilled robotic and } \\
\text { software engineers becoming a } \\
\text { new labour aristocracy? Will } \\
\text { the fate of displaced or } \\
\text { redundant labour become a } \\
\text { negotiating priority for trades } \\
\text { unions and workforces? } \\
\text { What new forms of control will } \\
\text { emerge with the emergence of } \\
\text { bid data in the agri-food } \\
\text { sector? }\end{array}$ \\
\hline $\begin{array}{l}\text { 'Uber- } \\
\text { isation' }\end{array}$ & $\begin{array}{l}\text { Mostly in high-income } \\
\text { economies but } \\
\text { emerging in middle- } \\
\text { income ones, too. }\end{array}$ & $\begin{array}{l}\text { Platform-based access to food } \\
\text { is on the rise, both for home } \\
\text { eating (e.g. Deliveroo, Uber, } \\
\text { Just-Eat and national } \\
\text { equivalents) and in home } \\
\text { delivery (e.g. Amazon Fresh, } \\
\text { Ocado) (Veen, Barratt, and } \\
\text { Goods 2019). }\end{array}$ & $\begin{array}{l}\text { It is championed as economic } \\
\text { 'disruption' which alters } \\
\text { previous power relations within } \\
\text { and between sectors. It is } \\
\text { associated with the 'gig' } \\
\text { economy of casualised labour. }\end{array}$ & $\begin{array}{l}\text { Will 'Uber-isation' give ever } \\
\text { more power to software } \\
\text { companies, patent holders and } \\
\text { brand ownership? Or will its } \\
\text { growth tail off or even turn out } \\
\text { to be a 'bubble', subject to the } \\
\text { whim of consumer take-up and } \\
\text { marketing budgets? Do gig- } \\
\text { food-workers enjoy their work } \\
\text { or is this new form of labour an } \\
\text { example of hyper-exploitation? }\end{array}$ \\
\hline $\begin{array}{l}\text { 'New' co- } \\
\text { operatives }\end{array}$ & $\begin{array}{l}\text { Attempts to create less } \\
\text { exploited labour } \\
\text { processes and } \\
\text { reconnect food } \\
\text { practices to people's } \\
\text { well-being has spawned } \\
\text { renewed interest in co- } \\
\text { operative and } \\
\text { alternative food } \\
\text { networks (Goodman, } \\
\text { DuPuis, and Goodman } \\
\text { 2012). }\end{array}$ & $\begin{array}{l}\text { This takes place in diverse } \\
\text { locations, e.g. Peasants and } \\
\text { smallholder farmers organising } \\
\text { in international fairtrade co- } \\
\text { operatives to achieve more } \\
\text { resilience and a better price, } \\
\text { and more localised 'alternative } \\
\text { food networks' linking towns } \\
\text { and their rural hinterland for } \\
\text { food supply (Goodman and } \\
\text { Sage 2014). }\end{array}$ & $\begin{array}{l}\text { These continue the long } \\
\text { tradition of labour forces } \\
\text { attempting to self-organise, } \\
\text { self-feed, and to share profits } \\
\text { more equitably than usual. It } \\
\text { ranges from small scale home } \\
\text { growing (allotments) to food } \\
\text { buying co-ops, to large social } \\
\text { enterprises and businesses. But } \\
\text { some argue that these } \\
\text { practices are hardly } \\
\text { autonomous and seldom free } \\
\text { of exploitation (Böhm et al., } \\
\text { 2016). }\end{array}$ & $\begin{array}{l}\text { What is the different } \\
\text { experience of labour in long } \\
\text { and short supply chains? } \\
\text { Where does control lie? Does } \\
\text { active participation in food } \\
\text { growing increase people's well- } \\
\text { being, and, if so, how? What } \\
\text { new modes of self-exploitation } \\
\text { exist in these cooperative } \\
\text { movements? }\end{array}$ \\
\hline $\begin{array}{l}\text { Low skilled } \\
\text { work }\end{array}$ & $\begin{array}{l}\text { This occurs throughout } \\
\text { the food system, e.g. } \\
\text { shelf-stackers and } \\
\text { checkout workers in } \\
\text { supermarkets, packers } \\
\text { in warehouses, and } \\
\text { dish-washers in cafés } \\
\text { and restaurants. }\end{array}$ & $\begin{array}{l}\text { Computerisation of ordering } \\
\text { means previously low status } \\
\text { work has to be included into } \\
\text { more technically ordered work, } \\
\text { such as using on-screen } \\
\text { categorisation. }\end{array}$ & $\begin{array}{l}\text { There is seemingly always a } \\
\text { demand for labour perceived as } \\
\text { low skilled because it is low } \\
\text { paid and low waged. We still } \\
\text { understand relatively little } \\
\text { about the manifold labour } \\
\text { processes in the agri-food } \\
\text { system. }\end{array}$ & $\begin{array}{l}\text { How low skilled is this work in } \\
\text { reality? Is such work likely to } \\
\text { grow or decline as other labour } \\
\text { trends occur? What does the } \\
\text { labour process actually look } \\
\text { like? How can wage income for } \\
\text { agri-food workers be increased } \\
\text { in rural, distant geographies? }\end{array}$ \\
\hline
\end{tabular}




\section{The special issue}

In this special issue we present papers that can be theoretically and empirically located within the organization of capital, work and labour in the global agri-food system in the way we have sketched out in this editorial. Specifically, authors explore how work and labour in the agri-food system have been shaped by the political economy of food and agriculture, and how these issues relate to other pertinent challenges, some old such as the persistence of hunger, food poverty and land grabbing; some new such as climate change, the obesity epidemic, and Big Data. At the same time, however, authors also discuss new forms of work and labour that resist dominant political economies of the agri-food system, showing pathways towards more sustainable, equitable and just futures. Let us now briefly introduce each paper to give you, the reader, an overview of this special issue on food and labour, the first of such kind within the field of organisation studies.

A lot of food that is bought by Global North consumers is now produced in Global South countries, where massive land grabs have given rise to many mega farms over the past two to three decades. Elisa Greco's paper discusses labour control and resistance in the context of such mega farms. Large-scale land investments in the Global South were hailed by the World Bank as offering possibilities to modernize farming and increase agricultural output (Arezki, Deininger, and Selod 2013). In line with critique expressed by Li (2011), Greco analyses cases in Uganda and Tanzania to study what impacts these investments have on labour and social reproduction. In her article she compares labour regimes on megarice farms with large-scale local rice farms. Despite the fact that 'gang' labour on local large-scale farms is also exploitative, labour on these farms is preferred to wage labour on the mega-rice farms. This is because locals see the work offered by these mega farms as undignified, exploitative and in conflict with their social reproduction. Greco's paper gives us a detailed insight into the real-existing food labour in countries such as Uganda and Tanzania, which is most often not seen and see-able by Global North consumers.

Yet, exploitative labour relations are not unique to the agri-food labour process in the Global South. The south of Spain has become one of the hotspots of intensive horticultural production, producing millions of tons of vegetables and fruit (under acres of plastic greenhouses) all year around, exporting them to mostly central and northern Europe. In their paper, Carlos de Castro, Alicia Reigada and Elena Gadea have studied food labour in the Murcia region (peaches, grapes, apricots) and the province of Huelva (strawberries), aiming to understand why and how female work has been devalued. They show that, in order to be competitive in the global agricultural supply chain, horticultural companies use business strategies aimed at the devaluation of female labour. Specifically, the paper explores the de-skilling of women's labour, the feminisation and segmentation of labour and the ethnic substitution and labour recruitment outsourcing mechanisms. By 'devaluation' the authors do not only mean that this work is poorly paid. For them, devaluation is a social process, which denies these female workers their social value.

It is often migrant labourers who perform the variety of devalued and precarious work in the agri-food industry. Inspired by their own experience as migrants and agri-food workers, Costa Manolchev and Celal Agar's paper explore migrant work from a spatial perspective. Using Lefebvre's 'rhythmanalysis' and Laban's 'ontology of rhythm', the authors offer a unique analysis of the everyday rhythms that migrants perform in their agri-food work. This rhythm perspectives enables them to conceptualise migrant agri-food labour as embodied space, which is continuously produced and reproduced for and with the workers. Crucially, however, these embodied rhythms also regulate, connect and dressage migrant workers' bodies. Often, migrant labour is understood from a legislative, sociological and cultural perspective. What Manolchev and Agar's paper offers is a more nuanced analysis of the everyday spatial experiences of agri-food workers, which is of utmost importance for our understanding of their exploitative and precarious nature.

What we know from decades of labour process analyses is that, if workers feel heavily controlled and exploited, then they are likely to resist at some point. Kandalat Raman's paper 'Can the Dalit Woman Speak?' is an intersectional study of resistance by Dalit tea pickers in Kerala, India. Using ethnography, historical and other secondary data, Raman gives an in-depth insight into work conditions at tea plantations and Dalit women's resistances to them. The paper explores how the women self-organized and how they were turned into political subjects through the struggle. Incorporating insights from postcolonial and labour process theory, as well as the feminist literature on intersectionality, the author is particularly interested in how normally disorganised people at the margins of society are able to organise and make themselves heard. So, when you, dear reader, have your next cup of tea, let us remember the multiple, intersectional oppressions experienced by Dalit women - and others - who have to sell their labour to make an often precarious living. 
Another form of resistance is when Global North consumers and citizens - who are now often very removed from the land - start becoming involved in growing their own food. A variety of alternative food movements have sprung up over the past decades, which show the distaste many people have for the global industrialised, commoditised and monopolised agri-food system. David Watson presents an in-depth analysis of an example of community-supported farming - referred to above as the creation of 'prosumers'. Watson offers an insider view as a participant in the scheme, and rich ethnographic details of how labour is organized in this particular example of community-supported farming. Watson analyses participants' work experiences, comparing them with Marxian analyses of the alienation of labour in capitalism, arguing that community-supported farming counteracts alienation. Consumers' labour connects people not only to the food they consume, but also raises awareness about environmental impacts of food production. Watson argues that community-supported farming thus increases both human and environmental well-being.

Alternative food initiatives tend to be very small-scale. Sophie Michel's paper explores what happens when actors try to scale up alternatives and transform the food system at the local level. Using institutional analysis of a French organization called M-LFP, Michel shows how, through collaborative institutional work and collective agency, a variety of actors within a region try to build an alternative food organisation that is able to challenge the dominant global food system. Yet, such attempts to institutionalise an alternative food system are often marked by multiple tensions, contradictions and compromises. Michel's paper should give all those who actively campaign and work for a different global food system some food for thought.

Sometimes it can be forgotten that many alternatives already exist - and have for a long time. Raquel Ajates Gonzalez's paper reminds us that food producer cooperatives have a long history and are widespread across the globe. Comparing cooperatives in the UK and Spain, she shows how their organizational forms have changed in response to changes in food markets, European agricultural policies and value chains. Ajates Gonzalez moves away from the dominant focus in research on the economic performance of cooperatives, to impacts of changes in policies and value chains on internal democratic processes. Pressures on cooperatives to remain competitive result in small farmers loosing voice in the cooperatives. Ajates Gonzalez refers to this as 'mainstreaming', which results in the co-optation of cooperatives and a loss of transformative powers to organize labour in a more socially just manner. Her paper reminds us that institutionalising alternative food movements and organisations does not necessarily lead - in the long run - to better work and labour practices.

We hope that the seven papers we have collated for this special issue will provide an invaluable insight into the work and labour dynamics in the global agri-food system. At the very least we see this collection as a call for organisational scholars to carry out further research into food and the daily work and labour that goes into producing, distributing and consuming it. We all need to eat. Without food humanity would cease to exist pretty quickly. It is time for organisation studies to take such basic process of social reproduction more seriously.

\section{Acknowledgments}

Steffen Böhm and Tim Lang acknowledge the funding provided by UKRI's Economic and Social Research Council, project ES/L001594/1 'The Future of our Food: Resilience, Security and Justice in a Global Context'

(https://gtr.ukri.org/projects?ref=ES\%2FL001594\%2F1). 


\section{References}

ACARD. (1982) The Food Industry and Technology. London: Cabinet Office, Advisory Committee on Applied Research and Development.

Ajates Gonzalez R. (2018) Farmers' Cooperatives and Sustainable Food Systems in Europe, Abingdon: Routledge.

Altieri, M. A. (2018). Agroecology: the science of sustainable agriculture. CRC Press.

Arntz M, Gregory T and Zierahn U. (2016) The Risk of Automation for Jobs in OECD Countries: a comparative analysis, Paris: OECD Publishing.

BBC (2019) 'Climate change food calculator: What's your diet's carbon footprint?', BBC News, 9 August 2019, https://www.bbc.co.uk/news/science-environment-46459714

Bernstein H. (2014) Food sovereignty via the 'peasant way': a sceptical view. Journal of Peasant Studies 41: 1031-1063.

Bharucha, Z. P., Weinstein, N., Watson, D., \& Böhm, S. (2019). Participation in local food projects is associated with better psychological well-being: evidence from the East of England. Journal of Public Health.

Bigliardia B and Galatib F. (2013) Innovation trends in the food industry: The case of functional foods. Trends in Food Science \& Technology 31: 118-129.

Binswanger, H. P., Deininger, K., \& Feder, G. (1995). Power, distortions, revolt and reform in agricultural land relations. Handbook of development economics, 3, 2659-2772.

Böhm, S., Bharucha, Z. P., \& Pretty, J. (Eds.). (2014). Ecocultures: blueprints for sustainable communities. Routledge.

Böhm, S., Misoczky, M. C., Watson, D., \& Lanka, S. (2016). Alternatives to Green Growth?: Possibilities and contradictions of self-managed food production.

Bose, S., \& Sugata, B. (1993). Peasant labour and colonial capital: Rural Bengal since 1770 (Vol. 2). Cambridge University Press.

Bradshaw T. (2019) The start-ups building 'dark kitchens' for Uber Eats and Deliveroo. Financial Times. London. 20 September. https://www.ft.com/content/a66619b0-77e4-11e9-be7d-6d846537acab

Brombin, A. (2015). Faces of sustainability in Italian ecovillages: food as 'contact zone'. International journal of consumer studies, 39(5), 468-477.

Bryceson, D. F. (2019). Gender and generational patterns of African deagrarianization: Evolving labour and land allocation in smallholder peasant household farming, 1980-2015. World Development, 113, 60-72.

Bryceson, D. F., Kay, C., \& Mooij, J. (2000). Disappearing Peasantries? Rural Labour in Africa, Asia and Latin America. London, UK: Intermediate Technology Publications.

Bundy C. (1972) The Emergence and Decline of a South African Peasantry. African Affairs 71: 369-388.

Cassidy ES, West PC, Gerber JS, et al. (2013) Redefining agricultural yields: from tonnes to people nourished per hectare. Environmental Research Letters 8: 034015.

Cernea, M. (1978). Macrosocial change, feminization of agriculture and peasant women's threefold economic role. Sociologia Ruralis, 18(2-3), 107-124.

Chan, K. W. (2010). The global financial crisis and migrant workers in China:'There is no future as a labourer; returning to the village has no meaning'. International Journal of Urban and Regional Research, 34(3), 659-677.

Clapp J. (2014) Financialization, distance and global food politics. Journal of Peasant Studies 41: 797-814.

Clarke K. (2016) Women and domestic service in Victorian society. London: History Press. https://www.thehistorypress.co.uk/articles/women-and-domestic-service-in-victorian-society/

Cliffe, L. (1978). Labour migration and peasant differentiation: Zambian experiences. The Journal of Peasant Studies, 5(3), 326-346.

Cousins B, Borras Jr SM, Sauer S, et al. (2018) BRICS, middle-income countries (MICs), and global agrarian transformations: internal dynamics, regional trends, and international implications. Globalizations 15: 1-11.

de la Mare U. (2008) Necessity and Rage: the Factory Women's Strikes in Bermondsey, 1911 History Workshop Journal 66: 62-80.

Defra (2019). Food Statistics Pocketbook 2018. London : Department for Environment, Food and Rural Affairs

Devlin S, Dosch T, Esteban A, et al. (2014) Urgent Recall: our food system under review. London: New Economics Foundation.

Devlin S. (2016) Agricultural labour in the UK. London: Food Research Collaboration.

Dorward A. (2013) Agricultural labour productivity, food prices and sustainable development impacts and indicators. Food Policy 39: 40-50.

Duncan J. (2015) Global Food Security Governance: Civil society engagement in the reformed Committee on World Food Security, Abingdon: Routledge. 
Elder SD and Dauvergne P. (2015) Farming for Walmart: the politics of corporate control and responsibility in the global South. Journal of Peasant Studies 42: 1029-1046.

European Commission. (2015) Big data for food, agriculture and forestry: opportunities and challenges", Big Data Europe workshop, Paris, 22 September 2015.

FAO, IFAD, ILO, et al. (2018) The linkages between migration, agriculture, food security and development. Rome: Food and Agriculture Organisation of the United Nations, 84pp.

Ferguson, R. S., \& Lovell, S. T. (2014). Permaculture for agroecology: design, movement, practice, and worldview. A review. Agronomy for Sustainable Development, 34(Fin24), 251-274.

FOLU (2019) Growing Better: Ten Critical Transitions to Transform Food and Land Use. London: Food and Land Use Coalition. https://www.foodandlandusecoalition.org/global-report/

Freudenberg N and Silver M. (2013) Jobs for a Healthier Diet and a Stronger Economy. Opportunities for Creating New Good Food Jobs in New York City. New York: Food Policy Center Hunter College \& City University of New York School of Public Health, 49.

Gabriel Y and Lang T. (2015) The Consumer as Worker. The Unmanageable Consumer. London: Sage, 235-251.

Gabriel Y. (1988) Working Lives in Catering, London: Routledge \& Kegan Paul

Gladek E, Fraser M, Roemers G, et al. (2016) The Global Food System: An Analysis - report to WWF. Amsterdam: WWF Netherlands and Metabolic. https://www.metabolic.nl/publications/global-food-system-an-analysis/

Goodman D, DuPuis EM and Goodman MK. (2012) Alternative food networks: knowledge, place and politics, London: Routledge.

Goodman MK and Sage C. (2014) Food Transgressions: Making Sense of Contemporary Food Politics Farnham: Ashgate, 268.

Grunert KG and Traill WB. (1997) Products and Process Innovation in the Food Industry. London: Blackie / Chapman and Hall.

Halliwell J. (2018) When will Amazon have the last laugh? (Oliver Wyman consultants survey). The Grocer. 12-13.

Hellard B. (2019) Grocers to use blockchain to track food by 2020. ITPRO newsletter: https://www.itpro.co.uk/blockchain/33546/grocers-to-use-blockchain-to-track-food-by-32020.

Herrera R and Kin CL. (2015) The struggle for food sovereignty: alternative development and the renewal of peasant societies today. London Pluto Press.

Higgs E and Wilkinson A. (2016) Women, Occupations and Work in the Victorian Censuses Revisited. History Workshop Journal: 17-38.

Hobsbawm EJ and Rudé GFE. (1969) Captain Swing, London: Lawrence and Wishart.

Hudson P. (2011) Women's Work. http://www.bbc.co.uk/history/british/victorians/womens_work_01.shtml. London: BBC.

International Labour Organisation. (2014) Protocol to the Forced Labour Convention http://www.ilo.org/wcmsp5/groups/public/---ed_norm/---

declaration/documents/publication/wcms_321414.pdf. Geneva: ILO.

International Labour Organisation. (2016) Women at Work: Trends 2016 Geneva: ILO.

International Labour Organisation. (2018a) Food, Drink and Tobacco Sector http://www.ilo.org/global/industries-andsectors/food-drink-tobacco/lang--en/index.htm [accessed Feb 11 2018]. Geneva: ILO.

International Labour Organisation. (2018b) World Employment and Social Outlook - Trends 2018. Geneva: ILO.

International Union of Foodworkers. (2007) Private Equity Funds: The harsh realities. Summary of Seminar held at the European Parliament, 19 April 2007. Geneva: IUF.

Kearney M. (2018) Reconceptualizing the peasantry: anthropology in global perspective: Routledge.

Kotler P. (1986) The prosumer movement: A new challenge for marketers. Advances in Consumer Research 13: 510-513.

Laite, J. (1981); Heywood, C. (1981). The role of the peasantry in French industrialization, 1815-80. The Economic History Review, 34(3), 359-376.

Lang T and Heasman M. (2015) Food Wars: the global battle for mouths, minds and markets, Abingdon: Routledge Earthscan.

Lanka, S. V., Khadaroo, I., \& Böhm, S. (2017). Agroecology accounting: biodiversity and sustainable livelihoods from the margins. Accounting, Auditing \& Accountability Journal, 30(7), 1592-1613.

Lawrence $G$ and Dixon J. (2015) The political economy of agri-food: Supermarkets. In: Alessandro Bonanno LB (ed) Handbook of the International Political Economy of Agriculture. Food. Edward Elgar, 213-.

Lewis, D. (2016). Bodies, matter and feminist freedoms: Revisiting the politics of food. Agenda, 30(Fin24), 6-16.

Li TM. (2011) Centering labor in the land grab debate. The Journal of peasant studies 38: 281-298. 
Lowe P, Phillipson J and Lee RP. (2008) Socio-technical innovation for sustainable food chains: roles for social science. Trends in Food Science \& Technology 19: 226-233.

Madichie, N. O., \& Yamoah, F. A. (2017). Revisiting the European horsemeat scandal: the role of power asymmetry in the food supply chain crisis. Thunderbird International Business Review, 59(6), 663-675.

Magnin C. (2016) How big data will revolutionize the global food chain. Paris: McKinsey \& Co.

Manyika J, Chui M, Miremadi M, et al. (2017) A Future That Works: Automation, Employment and Productivity. San Francisco: McKinsey Global Institute,, 28p.

Martinez-Torres ME and Rosset PM. (2010) La Via Campesina: The Evolution of a Transnational Movement. Journal of Peasant Studies 37: 149-175.

Mason P and Lang T. (2017) Sustainable Diets: How Ecological Nutrition can Transform Consumption and the Food System, Abingdon: Routledge Earthscan.

McMichael P. (2000) The Power of Food. Agriculture and Human Values 17: 21-33.

Moore, J. W. (2015). Capitalism in the Web of Life: Ecology and the Accumulation of Capital. Verso Books.

Nicholls, A., \& Opal, C. (2005). Fair trade: Market-driven ethical consumption. Sage.

OECD and FAO. (2015) OECD-FAO Guidance for Responsible Agricultural Supply Chains.

Pegler, L. (2015). Peasant inclusion in global value chains: economic upgrading but social downgrading in labour processes?. The Journal of Peasant Studies, 42(5), 929-956.

Perkins Gilman C. (1966 [1898]) Women and Economics: A Study of the Economic Relation Between Men and Women as a Factor in Social Evolution New York: Harper and Row.

Redfern P. (1920) The consumers' place in society, Manchester: Co-operative Union Limited.

Ricciardi V, Ramankutty N, Mehrabi Z, et al. (2018) How much of the world's food do smallholders produce? Global Food Security 17: 64-72.

Ritzer $\mathrm{G}$ and Jurgenson N. (2010) Production, Consumption, Prosumption - The nature of capitalism in the age of the digital 'prosumer' Journal of Consumer Culture 10: 13-36

Rosset, P. (2013). Re-thinking agrarian reform, land and territory in La Via Campesina. Journal of Peasant Studies, 40(Fin24), 721-775.

Rossman P. (2013) Eliminating precarious forms of work. Geneva: International Labour Organisation.

Scherrer C and Verma S. (2018) Decent Work Deficits in Southern Agriculture: Rainer Hampp Verlag, Augsburg, München.

Scott JC. (1976) The moral economy of the peasant: rebellion and subsistence in Southeast Asia, New Haven ; London: Yale University Press.

Sinclair U. (1906) Letter from Upton Sinclair to President Theodore Roosevelt, March 10, 1906 (National Archives Identifier: 301981); Letters Received, 1893 - 1906; Records of the Office of the Secretary of Agriculture, 1839 1981; Record Group 16 of US National Archives. Washington DC: National Archives.

Sinclair U. (1985 [1906]) The jungle, Harmondsworth: Penguin.

Slocum, R., \& Saldanha, A. (Eds.). (2016). Geographies of race and food: Fields, bodies, markets. Routledge.

Taylor M. (2017) Good work: the Taylor review of modern working practices. London: Department for Business, Energy \& Industrial Strategy.

Thomas WI and Znaniecki F. (1918) The Polish peasant in Europe and America: monograph of an immigrant group, Boston: G. Badger.

Thompson DJ. (1994) Weavers of dreams : the origins of the modern co-operative movement, Davis, CA: Center for Cooperatives University of California.

Thompson, C. J., \& Coskuner-Balli, G. (2007). Enchanting ethical consumerism: The case of community supported agriculture. Journal of consumer culture, 7(3), 275-303.

Van Bommel, K., \& Spicer, A. (2011). Hail the snail: Hegemonic struggles in the slow food movement. Organization studies, 32(12), 1717-1744.

van der Ploeg JD. (2008) The New Peasantries: Struggles for Autonomy and Sustainability in an Era of Empire and Globalization, London: Earthscan.

Vandergeest PJISSJ. (2018) Law and lawlessness in industrial fishing: frontiers in regulating labour relations in Asia. 68: 325-341.

Veen A, Barratt T and Goods C. (2019) Platform-Capital's 'App-etite' for Control: A Labour Process Analysis of FoodDelivery Work in Australia. Work, Employment and Society.

Walker KD. (2019) The Grand Food Bargain - and the Mindless Drive for More, Washington DC: Island Press.

White, M. M. (2011). Sisters of the soil: Urban gardening as resistance in Detroit. Race/ethnicity: Multidisciplinary global contexts, 5(1), 13-28. 
Willett W, Rockström J, Loken B, et al. (2019) Food in the Anthropocene: the EAT-Lancet Commission on healthy diets from sustainable food systems. The Lancet 392: https://doi.org/10.1016/S0140-6736(1018)31788-31784.

Winson A. (1993) The intimate commodity: food and the development of the agro-industrial complex in Canada, Toronto: Garamond Press.

World Bank. (2017) Future of Food: shaping the Food System to deliver jobs. Washington DC: World Bank Group.

World Bank. (2018) Employment in agriculture (\% of total employment) (modeled ILO estimate, 1991-2017).

https://data.worldbank.org/indicator/SL.AGR.EMPL.ZS [accessed Feb 2, 2018]. Washington DC: World Bank. 